\title{
The Essential Factor of Ventilation Rate in Prediction of Photosynthetic Rate Using the $\mathrm{CO}_{2}$ Balance Method
}

\author{
Ahmad Tusi ${ }^{1,2}$ and Teruaki Shimazu ${ }^{3 *}$ \\ ${ }^{1}$ The United Graduate School of Agricultural Science, Gifu University, Tokai National Higher Education and \\ Research System, Gifu 501-1193, Japan \\ ${ }^{2}$ Faculty of Agriculture, Lampung University, Bandar Lampung 35145, Indonesia \\ ${ }^{3}$ Faculty of Applied Biological Sciences, Gifu University, Tokai National Higher Education and Research System, \\ Gifu 501-1193, Japan
}

\begin{abstract}
Monitoring photosynthesis is a fundamental process to improve the yield and quality of plants in a greenhouse. The $\mathrm{CO}_{2}$ balance method is often employed to predict the photosynthetic rate of plants. We reviewed the essential parameters for predicting photosynthetic rates of plants canopy in greenhouses using the $\mathrm{CO}_{2}$ balance method. Even in a naturally ventilated greenhouse, ventilation rate is an essential parameter for the $\mathrm{CO}_{2}$ balance method, but it must be measured in real time as it fluctuates with weather conditions. We studied three types of ventilation rates (the tracer gas, heat balance, and water vapor balance methods). Comparing the measuring techniques of ventilation rate provided us an understanding of the strengths and weaknesses of each method. This knowledge can guide us to choosing the best method based on accuracy, device usage, practicality, and the installation budget. Most researchers have measured and controlled $\mathrm{CO}_{2}$ concentrations in a greenhouse using an infrared gas analyzer and predicted the ventilation rates using the tracer gas method. This method is suitable for the measurement of low and closed ventilation. The estimated ventilation rate by the heat balance method is recommended for large ventilation openings. The water vapor balance method is sufficient for measuring the ventilation rate when there is a large quantity of water vapor due to plant transpiration. The reliability of this method depends on the accuracy of short-term transpiration measurements. Improved water vapor balance techniques can benefit various greenhouse applications with different ventilator configurations, owing to the flexibility and ease of use compared to those of other methods.
\end{abstract}

\section{Keywords \\ heat balance, photosynthesis, tracer gas, ventilation rate, water vapor balance}

\section{Introduction}

Photosynthesis is crucial for increasing the yield and quality of crops; therefore, a thorough understanding of photosynthesis measurement in a greenhouse environment merits special attention. Photosynthetic process responds immediately to changes in the greenhouse climate, such as alterations in light intensity, air temperature, and $\mathrm{CO}_{2}$ concentration. Monitoring is required to determine whether the greenhouse climate is suitable to the needs of the crop. Real-time monitoring of net photosynthesis of a plant canopy in a greenhouse is crucial to elucidate and improve plant environments (Takakura et al., 2017). Leaf photosynthesis is measured by determining the $\mathrm{CO}_{2}$ uptake of a leaf using a portable gas exchanger device (Hao et al., 2008). The leaf chamber method has a high accuracy level as it controls the environment (light intensity, air temperature, humidity, $\mathrm{CO}_{2}$ concentration, and airflow rate) of the space where leaves are enclosed. However, the inner chamber is not always identical to the greenhouse environment, and is not suitable for long-term continuous measurement. To measure photosynthesis of an entire 
plant, Shimomoto et al. (2020) developed an open chamber method, using a transparent film supported by thin and light-weight steel frames and two ventilation fans, that measure photosynthesis and transpiration in a semicommercial greenhouse.

There are several methods to measure photosynthesis, such as the dry matter accumulation method (Lawlor et al., 1981), manometric method (Hunt, 2003), gas exchange method (Schulze, 1972; Takahashi et al., 2001), and phyto-monitoring application method (Dieleman et al., 2017). All forms of measurement had been reviewed for their advantages and disadvantages by Millan-Almaraz et al. (2009). The gas exchange method is the most utilized measurement in individual leaves, whole plants, and plant canopy for commercial equipment and experimental setup (Schulze, 1972; Millan-Almaraz et al., 2009). The gas exchange method is a suitable and convenient method for greenhouses as $\mathrm{CO}_{2}$ exchange can be readily measured.

The $\mathrm{CO}_{2}$ concentrations, both in the greenhouse and chamber, are determined by the gas supply from the $\mathrm{CO}_{2}$ generator, soil respiration, the photosynthesis/respiration reaction of plants, gas movement in the greenhouse due to ventilation, and exterior $\mathrm{CO}_{2}$ concentration level. These relationships are represented by a $\mathrm{CO}_{2}$ balance equation, which is used to calculate the photosynthetic rate in the chamber method. However, when the photosynthetic rate prediction by the $\mathrm{CO}_{2}$ balance method is applied to a naturally ventilated greenhouse, the ventilation rate becomes an unknown parameter as it fluctuates repeatedly depending on natural conditions. There are several techniques to predict the ventilation rate, such as tracer gas, heat balance, and water vapor balance techniques. If we could measure the parameters of the ventilation rate calculation simultaneously with the parameters of the $\mathrm{CO}_{2}$ balance equation, it would be possible to continuously monitor the photosynthetic rate of plants, even in a naturally ventilated greenhouse.

The air exchange rate (or ventilation rate) is an important parameter of the $\mathrm{CO}_{2}$ balance method and subsequently affects the $\mathrm{CO}_{2}$ concentration. Accurate gas exchange rate measurements improve the accuracy of photosynthetic rate estimation. This review focuses on the photosynthetic rate measurements using $\mathrm{CO}_{2}$ gas exchange at the greenhouse scale (including the physical and technical aspects); it also evaluates and compares the ventilation rates across tracer gas, heat balance, and water vapor balance techniques. A sufficiently detailed summary of the literature addressing photosynthesis measurement in greenhouses based on the $\mathrm{CO}_{2}$ gas exchange and ventilation rate method is provided.

\section{Measurement of photosynthetic rate in a greenhouse}

A photosynthesis/transpiration measuring system (LI-6400XT, LI-6800 from LI-COR Co., USA) is commonly used to measure leaf photosynthetic rates on a fully expanded foliage. This system can control light, temperature, humidity, and $\mathrm{CO}_{2}$ concentration in the leaf chamber (Hao et al., 2008; Thwe et al., 2014; Albert et al., 2017). The portable photosynthetic device, LI-6400XT, measures the gas exchange of a leaf specimen or a sample isolated in a closed chamber; thus, $\mathrm{CO}_{2}$ exchange can be measured (Schulze, 1972; Takahashi et al., 2001). There are two types of gas exchange chambers: a closed chamber (where the sample is completely enclosed), and an open chamber (where air can freely enter and leave the chamber), as reported by Hunt (2003). Measurement with a portable device is done manually and does not allow on-line monitoring of crop photosynthesis (Dieleman et al., 2017). For whole plant photosynthesis monitoring, Shimomoto et al. (2020) developed a system with an open chamber in a greenhouse to evaluate the dynamic changes in photosynthesis of crops. This system used a transparent film to cover the crops that would possibly impact the different environments inside an open chamber with the outer chamber environmental conditions. Schulze (1972) and Millan-Almaraz et al. (2009) reported that the gas exchange method is suitable for estimating photosynthesis in a greenhouse environment. Thus, this paper focuses only on photosynthesis measurements using the gas exchange method. 
The net canopy photosynthesis of crops measurement had been described in detail by Hand (1973a) under a daylight controlled-environment cabinet. In addition, Hand (1973b) reviewed many different methods of gas exchange measurement in which the plant enclosures can be of open, closed, or mixed systems. Furthermore, Lake et al. (1968) had applied an open system with null point compensation for $\mathrm{CO}_{2}$, whereas the $\mathrm{CO}_{2}$ concentration inside the greenhouse was maintained at almost the same level as the $\mathrm{CO}_{2}$ level outside (or $\Delta \mathrm{CO}_{2} \approx 0$ ). Generally, the $\mathrm{CO}_{2}$ gas exchange method was used to measure photosynthesis based on $\mathrm{CO}_{2}$ concentration changes both inside and outside the greenhouse. It is also known as the $\mathrm{CO}_{2}$ balance method, as presented in Eq. 1. $\mathrm{CO}_{2}$ greenhouse fluxes are based on ventilation, $\mathrm{CO}_{2}$ supply, $\mathrm{CO}_{2}$ from soil respiration, changes in the greenhouse $\mathrm{CO}_{2}$ concentration, and net photosynthesis.

$$
\frac{V}{w A} \frac{d C_{\text {in }}}{d t}=I+S+\frac{G}{w}\left(C_{\text {out }}-C_{\text {in }}\right)-P_{n}
$$

where $V$ and $A$ are, respectively, the volume $\left(\mathrm{m}^{3}\right)$ and the cultivable ground area $\left(\mathrm{m}^{2}\right)$ of the greenhouse; $d C_{i n} / d t$ is the time change of $\mathrm{CO}_{2}$ concentration in the greenhouse $\left(\mu \mathrm{mol} \mathrm{mol}^{-1} \mathrm{~min}^{-1}\right) ; w$ is the molar volume of standard air $\left(\approx 0.0224 \mathrm{~m}^{3} \mathrm{~mol}^{-1}\right.$ at $\left.20^{\circ} \mathrm{C}, 101.325 \mathrm{kPa}\right) ; I$ is the $\mathrm{CO}_{2}$ injection flux or supply $\left(\mu \mathrm{mol} \mathrm{m}^{-2} \mathrm{~min}^{-1}\right) ; S$ is the $\mathrm{CO}_{2}$ output from soil respiration $\left(\mu \mathrm{mol} \mathrm{m} \mathrm{min}^{-1}\right)$; $G$ is the ventilation flux $\left(\mathrm{m}^{3} \mathrm{~m}^{-2} \mathrm{~min}^{-1}\right), C_{i n}$ is the $\mathrm{CO}_{2}$ concentration inside the greenhouse $\left(\mu \mathrm{mol} \mathrm{mol}^{-1}\right)$; $C_{\text {out }}$ is the concentration of $\mathrm{CO}_{2}$ outside the greenhouse $\left(\mu \mathrm{mol} \mathrm{mol}^{-1}\right)$; and $P_{n}$ represents the net photosynthetic rate per floor area $\left(\mu \mathrm{mol} \mathrm{m} \mathrm{min}^{-1}\right)$.

Several authors considered that the difference between $\mathrm{CO}_{2}$ concentration inside and outside the greenhouse was null, and that the $\mathrm{CO}_{2}$ respiration from soil was negligible due to plastic covering (Hand, 1973a; Hand et al., 1992; Zekki et al., 1999). When the null balance concept was applied (Hand, 1973a), the $\mathrm{CO}_{2}$ concentration in the greenhouse was maintained at the same level as the ambient $\mathrm{CO}_{2}$ concentration outside (around 350-380 $\mu \mathrm{mol} \mathrm{mol}^{-}$ ${ }^{1}$ ), and the effect of the $\mathrm{CO}_{2}$ exchanges inside and outside the greenhouse was minimized.

The net photosynthesis equation can be determined based on greenhouse $\mathrm{CO}_{2}$ concentration and the injected $\mathrm{CO}_{2}$ in the system. When the ventilation rate (or leakage) and the soil respiration are negligible $(G, S \approx 0)$, the net photosynthesis rate is calculated by modifying Eq. 1 as follows;

$$
P_{n}=I-\frac{V}{w A} \frac{d C_{i n}}{d t}
$$

An infrared gas analyzer (IRGA) was used to measure the $\mathrm{CO}_{2}$ concentrations of samples taken using a nylon tube placed within the canopy at mid-height in the greenhouse (Hand et al., 1992; Zekki et al., 1999). Figure 1 shows a schematic diagram of the $\mathrm{CO}_{2}$ measurement, control, and distribution systems, as reported by Hand et al. (1992). Based on the equation of the $\mathrm{CO}_{2}$ balance methods (Eq. 1) and a schematic diagram of the $\mathrm{CO}_{2}$ measurement and control (Figure 2), there are three critical parameters: 1) changes in $\mathrm{CO}_{2}$ concentration, 2) control of $\mathrm{CO}_{2}$ supply, and 3) ventilation rate. The $\mathrm{CO}_{2}$ concentration is controlled to an ambient level. The amounts of $\mathrm{CO}_{2}$ used in the canopy zone were measured with linear mass flowmeters. The ventilation rate factor was negligible in Hand et al. (1992), because of the $\mathrm{CO}_{2}$ concentration being maintained at the same level both inside and outside the greenhouse. In contrast, the ventilation rate should be added to the $\mathrm{CO}_{2}$ balance calculation at a moderate or high ventilation rate condition, as given by Nederhoff et al. (1989), Ehler (1991), and Chalabi and Fernandez (1994) confirming that the ventilation rate is significant for predicting photosynthetic rate based on the $\mathrm{CO}_{2}$ balance method. This is especially true during the late spring and summer seasons when there is high solar radiation and windows are therefore opened for temperature control. 


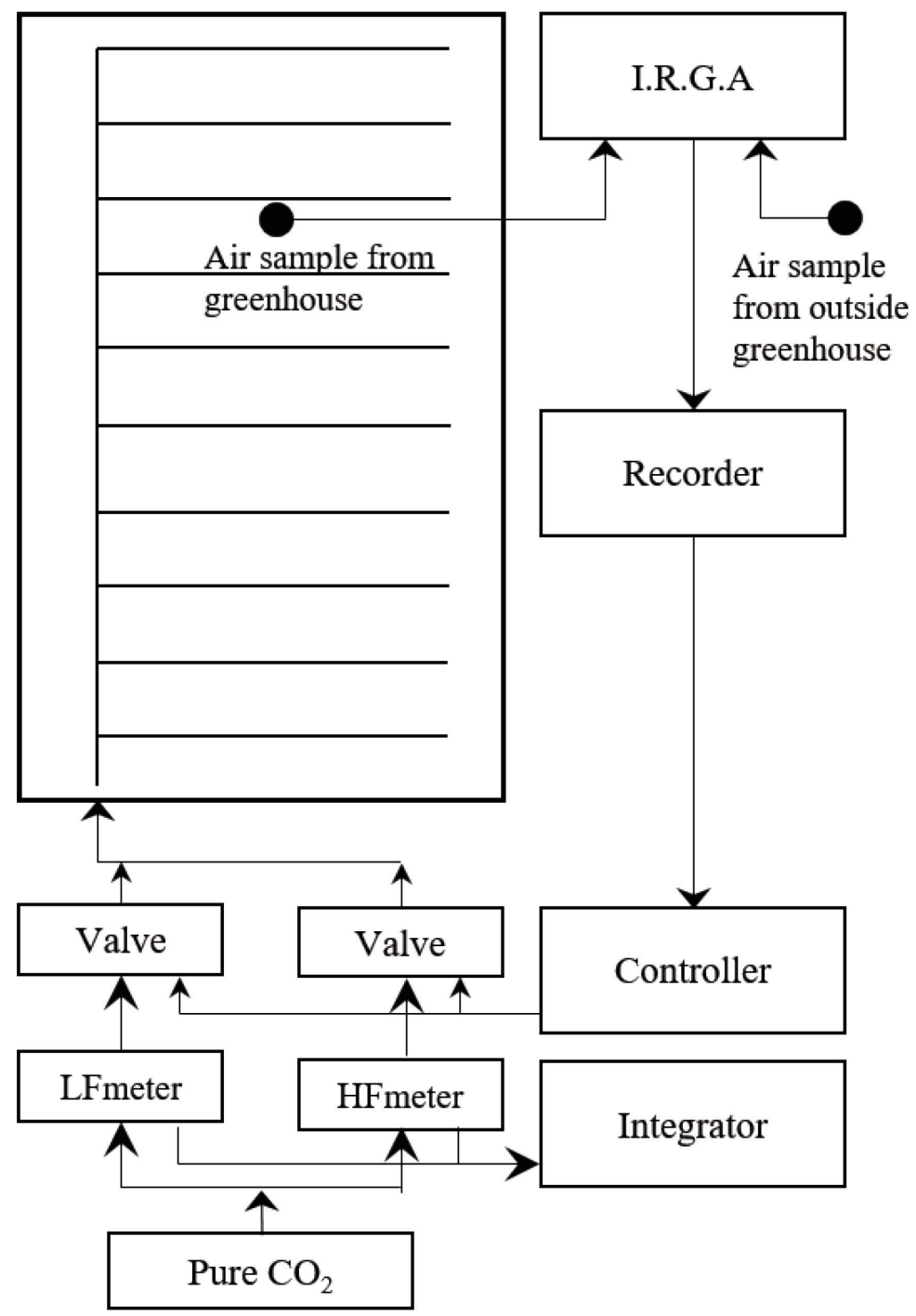

Figure 1: Schematic diagram of the $\mathrm{CO}_{2}$ measurement, control and distribution using an infrared gas analyzer, IRGA (Hand et al., 1992). $\mathrm{CO}_{2}$ supplied from the cylinders was metered through linear mass flowmeters (Teledyne Hastings-Raydist type HS) with the ranges 0 $20 \mathrm{~g} \mathrm{CO}_{2} \mathrm{~min}^{-1}$ (low flowmeter, $\mathrm{LF}$ ) and 0-60 $\mathrm{g} \mathrm{CO}_{2} \mathrm{~min}^{-1}$ (high flowmeter, $\mathrm{HF}$ ).

Table 1 shows the photosynthetic rate in a greenhouse calculated based on a greenhouse climate system (Nederhoff et al., 1989; Gijzen et al., 1990; Chalabi and Fernandez, 1994; Zekki et al., 1999; Zhang and Wang, 2011; Wang et al., 2013) and plant monitoring (Dieleman et al., 2017). Studies have shown that ventilation rate can be calculated as an unknown parameter in the $\mathrm{CO}_{2}$ balance equation, using the tracer gas technique with $\mathrm{N}_{2} \mathrm{O}$ (Nederhoff et al., 1989; Gijzen et al., 1990; Ehler, 1991). They determined the ventilation rate using $\mathrm{N}_{2} \mathrm{O}$ tracer gas under leakage and a small window aperture (therefore a low ventilation rate). Furthermore, Takakura et al. (2017) calculated the canopy photosynthesis based on the $\mathrm{CO}_{2}$ balance and the ventilation rate using the energy balance technique under a high ventilation rate condition.

Dieleman et al. (2017) conducted plant monitoring based on crop measurement techniques using the Crop Photosynthesis Monitor (for measuring crop photosynthesis) and the CropObserver (for measuring 
photosynthetically active radiation and fluorescence of a large area of the crop). These monitoring systems provided reasonable estimations of crop photosynthesis when compared with those of the crop growth model (Marcelis et al., $2000)$ at a small-scale interval measurement $(15 \mathrm{~min})$. However, further development of these systems is required before they will be incorporated into greenhouse climate systems.

Table 1: Summary of reviewed literature suggesting photosynthesis rate measurement and simulation in the greenhouse system from 1989 to 2017

\begin{tabular}{|c|c|c|c|}
\hline Year & Photosynthesis (measurement/model) & $\begin{array}{l}\text { Measurement methods of } \\
\text { ventilation rate }\end{array}$ & References \\
\hline 1989 & Dynamic simulation model using the $\mathrm{CO}_{2}$ balance method & Tracer gas using $\mathrm{N}_{2} \mathrm{O}$ & Nederhoff et al. (1989) \\
\hline 1990 & $\begin{array}{l}\text { Measurement of photosynthesis using a } \mathrm{CO}_{2} \text { balance } \\
\text { method every } 30 \mathrm{~min}\end{array}$ & Tracer gas using $\mathrm{N}_{2} \mathrm{O}$ & Gijzen et al. (1990) \\
\hline 1991 & $\begin{array}{l}\text { An hourly net photosynthesis measurement using } \mathrm{CO}_{2} \\
\text { balance method at a low ventilation rate }\end{array}$ & Tracer gas & Ehler (1991) \\
\hline 1994 & $\begin{array}{l}\text { Estimation of canopy photosynthesis based on } \mathrm{CO}_{2} \text { balance } \\
\text { method }\end{array}$ & $\begin{array}{l}\text { The using model developed } \\
\text { by Fernandez and Bailey } \\
\text { (1992); function of wind } \\
\text { speed and the opening angle }\end{array}$ & $\begin{array}{l}\text { Chalabi and Fernandez } \\
\text { (1994) }\end{array}$ \\
\hline 1999 & $\begin{array}{l}\text { Measurement of net photosynthetic rate using the } \mathrm{CO}_{2} \\
\text { balance method }\end{array}$ & $\begin{array}{l}\text { Negligible (null } \mathrm{CO}_{2} \\
\text { balance) }\end{array}$ & Zekki et al. (1999) \\
\hline 2017 & Monitoring of a plant canopy using $\mathrm{CO}_{2}$ balance technique & Energy balance method & Takakura et al. (2017) \\
\hline 1991 & $\begin{array}{l}\text { The black box model of the photosynthesis simulation } \\
\text { model }\end{array}$ & - & Ehler (1991) \\
\hline 1994 & $\begin{array}{l}\text { Simulation of canopy photosynthesis based on mechanistic } \\
\text { models (Acock model, and Challa and Schapendonk } \\
\text { model) }\end{array}$ & - & $\begin{array}{l}\text { Chalabi and Fernandez } \\
\text { (1994) }\end{array}$ \\
\hline 1999 & $\begin{array}{l}\text { Simulation of photosynthesis using the TOMGRO model } \\
\text { which integrates Acock's model }\end{array}$ & - & Zekki et al., (1999) \\
\hline 2011 & $\begin{array}{l}\text { Simulation of photosynthesis based on simple leaf } \\
\text { photosynthesis after the careful consideration of leaf area } \\
\text { index and light density distribution in the greenhouse and } \\
\text { considered the influence of the environment (temperature, } \\
\mathrm{CO}_{2} \text { concentration, and moisture). }\end{array}$ & - & Zhang and Wang (2011) \\
\hline 2013 & $\begin{array}{l}\text { Model of monitoring photosynthesis based on } \mathrm{CO}_{2} \\
\text { concentration and photosynthesis data measurements } \\
\text { analyzed using the back-propagation neural network } \\
\text { model. }\end{array}$ & - & Wang et al. (2013) \\
\hline
\end{tabular}




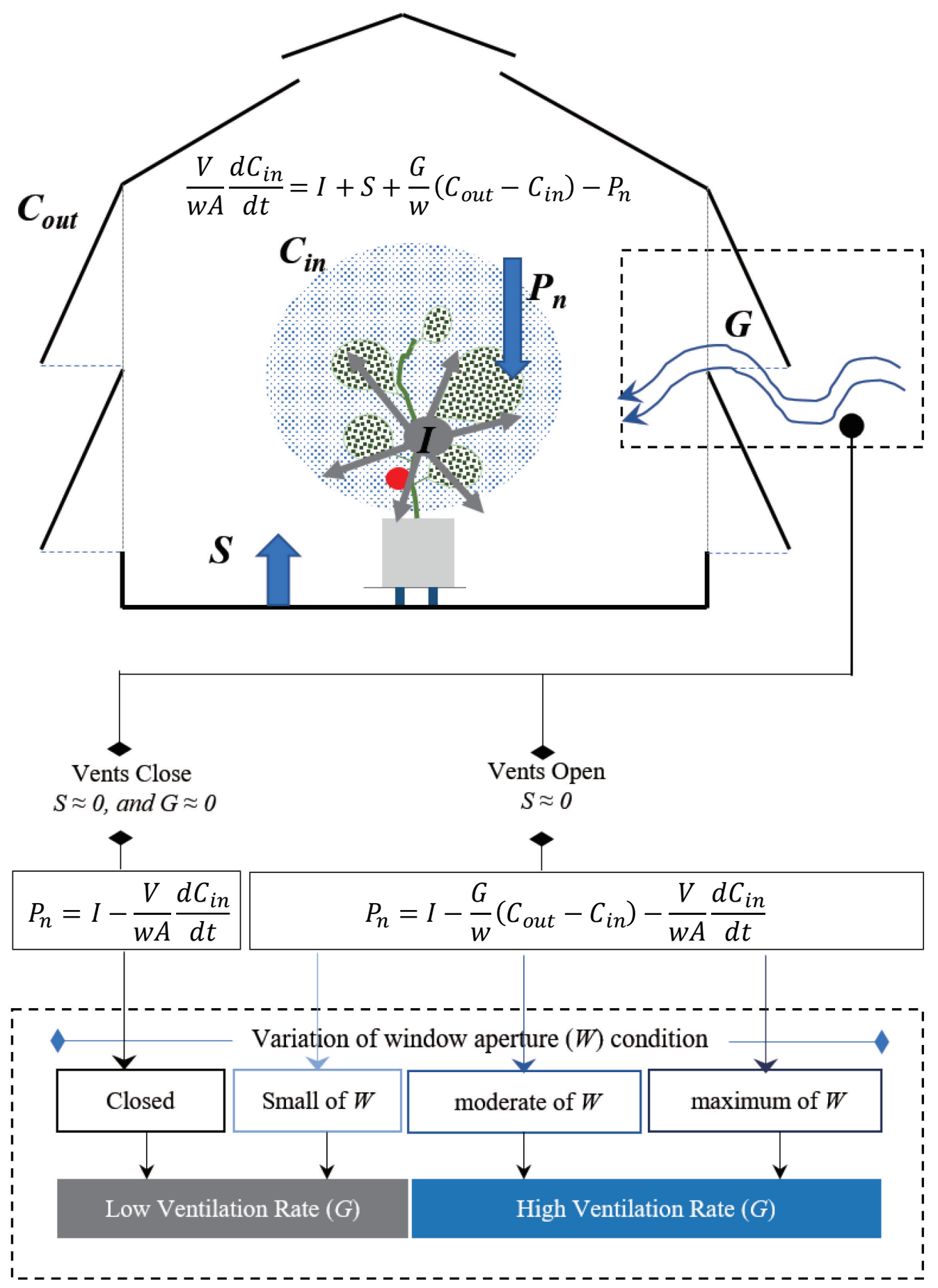

Figure 2: Schematic diagram of the $\mathrm{CO}_{2}$ balance method with $\mathrm{CO}_{2}$ supply $(I)$ in a greenhouse for estimating the photosynthetic rate $\left(P_{n}\right)$. The changes of concentration between outside and inside $\left(C_{\text {out }}-C_{i n}\right)$ and the changes of inside concentration during the time of measurement $\left(d C_{i n}\right)$ in total volume $(V)$ per floor area of greenhouse $(A)$, are affected by window aperture $(W)$ condition, as presented by ventilation rate value $(G)$. Assuming the $\mathrm{CO}_{2}$ release from the soil was zero $(S \approx 0)$ due to being covered by plastic and using the hydroponic cultivation method (with soilless culture). 


\section{3. $\mathrm{CO}_{2}$ measurements in greenhouse}

$\mathrm{CO}_{2}$ fertilization effectively promotes photosynthesis in cases where the $\mathrm{CO}_{2}$ concentration in the community is higher than that in the outside air. $\mathrm{CO}_{2}$ depletion of 5-10\% below ambient is typical for an adequately ventilated greenhouse on warm and sunny days. $\mathrm{CO}_{2}$ concentration can further decrease in winter and spring due to closed windows in greenhouses (Hand, 1985); hence, it is crucial to measure the $\mathrm{CO}_{2}$ concentration accurately. Accurate $\mathrm{CO}_{2}$ concentration data in a greenhouse is critical for controller design and actuator control. Many growers operate the actuators based only on their experience (Rodríguez et al., 2015). The development of sensor technology has allowed the objective monitoring of greenhouse parameters, but accurate measurements of $\mathrm{CO}_{2}$ concentration are difficult because $\mathrm{CO}_{2}$ is not homogenous in the greenhouse.

The most common equipment used for $\mathrm{CO}_{2}$ measurement is the infrared gas analyzer (IRGA) (Hand, 1973a; Nederhoff et al., 1989; Ehler, 1991; Chalabi and Fernandez, 1994; Zekki et al., 1999). This sensor uses an infrared emitter-photodetector pair whose light beam measures the concentration of gas molecules in the air. In addition to using the IRGA, the $\mathrm{CO}_{2}$ concentration can be determined using a simple $\mathrm{CO}_{2}$ engine $\mathrm{K} 30$ sensor (Senseair AB Co., Sweden), as shown by Takakura et al. (2017).

In a $\mathrm{CO}_{2}$ monitoring system, the spatial distribution of $\mathrm{CO}_{2}$ concentration, which is relevant to crop growth, needs to be considered (Li et al., 2018). Analyzing this spatial distribution is complex and requires a specific tool. Computational fluid dynamics (CFD) involves simulating flow fields based on the conservation equations of mass and energy. It is suitable for analyzing non-uniform data and has been used successfully in prior studies. CFD can also explore the $\mathrm{CO}_{2}$ distribution within a greenhouse for optimal control (Boulard et al., 2017).

The differences in vertical $\mathrm{CO}_{2}$ distribution are not significant in a greenhouse (Li et al., 2018). Therefore, $\mathrm{CO}_{2}$ sensors are placed in locations where they are easy to operate. However, in some sophisticated greenhouses, horizontal or vertical changes in $\mathrm{CO}_{2}$ concentration were complex. In general, the vertical distribution of $\mathrm{CO}_{2}$ concentration is low in the canopy, while it is high air above the canopy and the soil surface (Chalabi and Fernandez, 1994; Kim et al., 2015). The horizontal $\mathrm{CO}_{2}$ concentration at the height of the canopy was relatively uniform. Therefore, the sensor is commonly placed approximately at the height of the crop canopy (Li et al., 2018).

The control of $\mathrm{CO}_{2}$ was actuated by a valve for injecting $\mathrm{CO}_{2}$ fertilizer in a short time to maintain the desired $\mathrm{CO}_{2}$ concentration level. Then, the canopy photosynthesis rate using the $\mathrm{CO}_{2}$ balance can be predicted with a shorttime interval calculation (Figure 3). Studies have calculated the photosynthetic rate between and 5-15 min (Ehler, 1991; Chalabi and Fernandez, 1994; Zekki et al., 1999) based on the $\mathrm{CO}_{2}$ balance method and tracer gas analysis (Figure 3). Takakura et al. (2017) calculated the canopy photosynthesis every minute using the $\mathrm{CO}_{2}$ balance and the energy balance method. However, there was a problem with scattered data due to frequent changes in the ventilation amount. Advanced technology is needed to control the $\mathrm{CO}_{2}$ concentration supply based on real-time $\mathrm{CO}_{2}$ concentration conditions, ventilation rate prediction, and photosynthesis calculations.

Li et al. (2018) categorized various control methods for $\mathrm{CO}_{2}$ concentration: conventional control (ON-OFF control), proportional-integral-differential (PID) control; modern control (non-linear, robust, and optimal control); intelligent control (fuzzy, neural network control); hybrid control (fuzzy PID, neural network PID, fuzzy neural network) and others such as CFD and machine vision. Lee et al. (2000) conducted a PID algorithm in a tunnel-type chamber to maintain the temperature gradient from the inlet to the outlet by automatic ventilation rate control. 


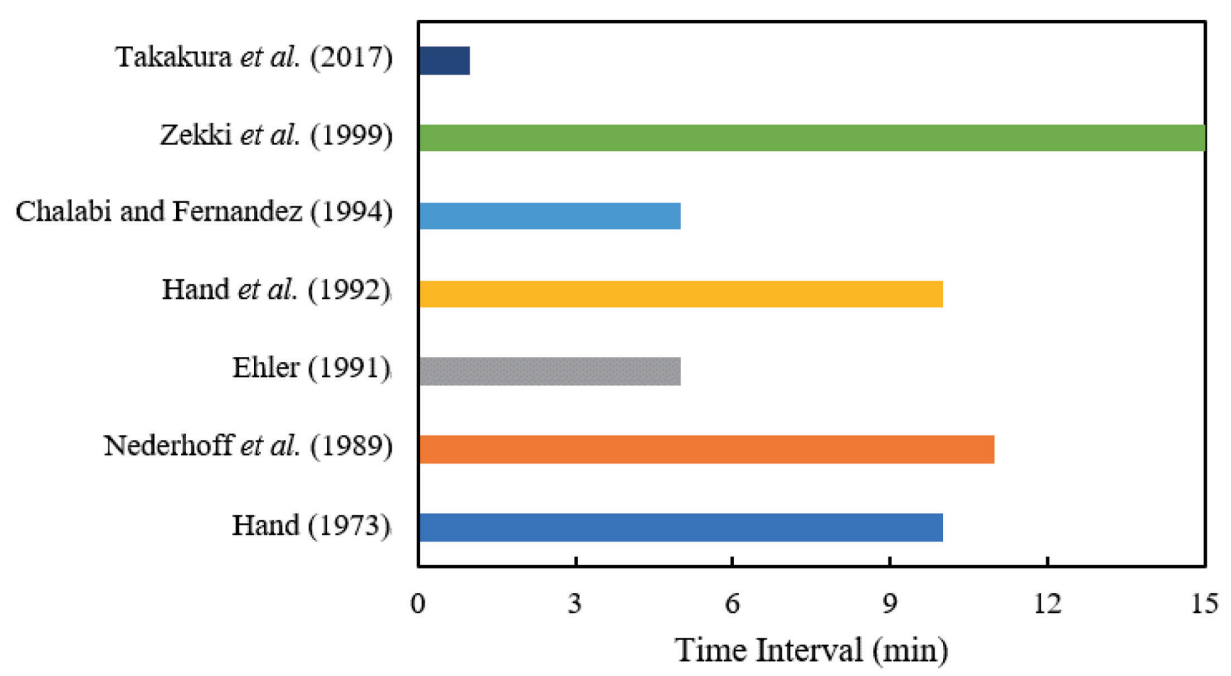

Figure 3: The interval time of photosynthetic rate measurement in different sources based on the $\mathrm{CO}_{2}$ balance method

Based on the mass $\mathrm{CO}_{2}$ balance model literature, as shown in Table 2 and Figure 3, it is clear that the $\mathrm{CO}_{2}$ balance using the null balance method is intended to work at low ventilation rates (Zekki et al., 1999; Hand et al., 1992) and at long-interval calculations of photosynthesis (10-15 min). In contrast, the ventilation rate should be added to the $\mathrm{CO}_{2}$ balance calculation at moderate or high ventilation rate conditions with interval calculations of photosynthesis between 5-11 min, as shown in Nederhoff et al. (1989), Ehler (1991), and Chalabi and Fernandez (1994).

$\mathrm{CO}_{2}$ loss still exists even when the ventilation rate is assumed to be zero (as in the null balance concept), but the amount of $\mathrm{CO}_{2}$ loss by this process is small compared with the amount at higher ventilation rate conditions. Hence, infiltration should not be neglected, even with closed windows. Therefore, it is vital to add and evaluate the ventilation rate performance used in the $\mathrm{CO}_{2}$ balance equations.

The calculated photosynthetic rate using the $\mathrm{CO}_{2}$ balance has not yet been validated in a naturally ventilated greenhouse. It is essential to compare and verify the measurement of photosynthesis rate based on 1) the $\mathrm{CO}_{2}$ balance method with ventilation rate prediction and 2) the leaf chamber method. Moreover, there is a lack of information on accurate and continuous measurement techniques for ventilation as a parameter of the $\mathrm{CO}_{2}$ balance method. Therefore, further research is needed under different window apertures, from low to high ventilation rates.

\section{Ventilation rate prediction in greenhouse}

An essential tool for controlling greenhouse microclimate is ventilation. Air exchange between the interior and exterior of a greenhouse influences environmental conditions such as temperature, humidity, and $\mathrm{CO}_{2}$ concentration, thereby influencing the development and production of the crop.

The measurement of the ventilation rate in a greenhouse involves various environmental parameters. It is a complex mechanism, including heat transfer processes of conduction, convection, and/or radiation. There is no single method to measure the ventilation rate because it is not only influenced by the microclimate and the presence of crop conditions, but it is also affected by the structure and design of the greenhouse. 
Various techniques have been used to measure and predict the ventilation rate, such as the tracer gas method (Boulard and Draoui, 1995; Papadakis et al., 1996; Baptista et al., 1999), heat balance method (Fernandez and Bailey, 1992; Demrati et al., 2001; Harmanto et al., 2006a), and water vapor balance method (Boulard and Draoui, 1995; Harmanto et al., 2006a).

Table 2: Summary of reviewed literature suggesting photosynthesis rate measurement using the $\mathrm{CO}_{2}$ balance method

\begin{tabular}{|c|c|c|c|c|c|}
\hline \multicolumn{2}{|c|}{$\mathrm{CO}_{2}$ concentration } & \multirow{2}{*}{$\begin{array}{c}\text { Measurement method } \\
\text { of ventilation rate }\end{array}$} & \multirow[t]{2}{*}{ Ventilator } & \multirow[t]{2}{*}{ Model Comparison } & \multirow[t]{2}{*}{ Authors } \\
\hline$\mu \mathrm{mol} \mathrm{mol}{ }^{-1}$ & device & & & & \\
\hline 350 & IRGA & (null balance method) & Closed all-day & $\begin{array}{l}\text { TOMGRO model } \\
\text { (a mechanistic model) }\end{array}$ & Zekki et al. (1999) \\
\hline 350 & IRGA & (null balance method) & $\begin{array}{l}\text { Closed and small } \\
\text { ventilator }\end{array}$ & $\begin{array}{l}\text { Empirically based on a } \\
\text { quadratic regression } \\
\text { mechanistic model as } \\
\text { developed by Thornley et } \\
\text { al. (1992) }\end{array}$ & Hand et al. (1992) \\
\hline $350-1000$ & IRGA & $\begin{array}{l}\text { Model as developed } \\
\text { by Fernandez and } \\
\text { Bailey, 1992) }\end{array}$ & Small ventilator & $\begin{array}{l}\text { Mechanistic model: Acock } \\
\text { et al., (1978) and Challa } \\
\text { and Schapendonk (1984) }\end{array}$ & $\begin{array}{l}\text { Chalabi and } \\
\text { Fernandez (1994) }\end{array}$ \\
\hline $350-1500$ & IRGA & Tracer gas $\left(\mathrm{N}_{2} \mathrm{O}\right)$ & Small ventilation & $\begin{array}{l}\text { The SUCROS model } \\
\text { (Gijzen and Ten Cate, } \\
\text { 1988) }\end{array}$ & $\begin{array}{l}\text { Nederhoff } \text { et al. } \\
\text { (1989) }\end{array}$ \\
\hline $350-1000$ & $\begin{array}{l}\text { DGT infrared } \\
\mathrm{CO}_{2} \text { scanner } \\
\text { (IRGA) }\end{array}$ & Tracer gas $\left(\mathrm{N}_{2} \mathrm{O}\right)$ & $\begin{array}{l}\text { Low and high } \\
\text { ventilation }\end{array}$ & $\begin{array}{l}\text { The black box model of } \\
\text { the photosynthesis } \\
\text { simulation model }\end{array}$ & Ehler (1991) \\
\hline $400-1200$ & IRGA & Tracer gas $\left(\mathrm{N}_{2} \mathrm{O}\right)$ & Low ventilation & - & Hand (1973a) \\
\hline $\begin{array}{l}\text { No } \\
\text { information }\end{array}$ & $\begin{array}{l}\mathrm{CO}_{2} \text { engine } \\
\mathrm{K} 30\end{array}$ & $\begin{array}{l}\text { Energy balance } \\
\text { method }\end{array}$ & Low ventilation & - & $\begin{array}{l}\text { Takakura et al. } \\
\text { (2017) }\end{array}$ \\
\hline
\end{tabular}

\subsection{Tracer gas technique}

The tracer gas technique is the most common technique for measuring the ventilation rate and leakage rates [Nederhoff et al. (1985), Fernandez and Bailey (1992), Boulard and Draoui (1995), Kittas et al. (1996), Baptista et al. (1999), Kittas et al. (2002), and Katsoulas et al. (2006)]. It works based on a mass balance method or the principle of mass conservation and is mostly used to estimate ventilation rates directly.

Various gases have been used as tracer gases, such as sulfur hexafluoride $\left(\mathrm{SF}_{6}\right)$, methane $\left(\mathrm{CH}_{4}\right)$, argon 41 , Krypton 85, nitrous oxide $\left(\mathrm{N}_{2} \mathrm{O}\right)$, and carbon dioxide $\left(\mathrm{CO}_{2}\right)$. For ventilation rate analysis in a greenhouse, these gases should have the following characteristics: workable at low concentrations, nontoxic, non-flammable, inert, not naturally occurring in air, and weighing close to the average molecular weight of the air component (Goedhart et al., 1984; Sherman, 1990). The most frequently used are $\mathrm{CO}_{2}$ (Nederhoff et al., 1985; Boulard and Baile, 1995) and $\mathrm{N}_{2} \mathrm{O}$ (Fernandez and Bailey, 1992; Baptista et al., 1999; Kittas et al., 2002; Katsoulas et al., 2006), and there are some advantages and disadvantages relating to both of these. 
Baptista et al. (1999) suggested $\mathrm{N}_{2} \mathrm{O}$ as a tracer gas because it meets all the above requirements and is not influenced by the photosynthesis and respiration of the plants. A tracer gas with $\mathrm{N}_{2} \mathrm{O}$ is inert for plants and mixes well with air; however, water vapor can influence the infrared absorption used for tracing $\mathrm{N}_{2} \mathrm{O}$ gas (Goedhart et al., 1984). In addition, it requires additional operational costs for the grower.

$\mathrm{CO}_{2}$ can be used as a tracer gas, but it is necessary to measure the $\mathrm{CO}_{2}$ concentration within the greenhouse and also the $\mathrm{CO}_{2}$ release rate from the soil. $\mathrm{CO}_{2}$ is also influenced by the $\mathrm{CO}_{2}$ exchange of the plants; however, this problem can be solved, as proposed by Nederhoff et al. (1985), by using a practical method for measuring leakage and low-level ventilation greenhouses based on $\mathrm{CO}_{2}$ as a tracer gas. In addition, they suggested that the proposed method could be used in practice after comparing with the infrared gas analyzer. There are particular advantages of using $\mathrm{CO}_{2}$ as a tracer gas. It not only stimulates plant growth but also determines the ventilation. Thus, both types of gas have advantages and disadvantages, but the $\mathrm{CO}_{2}$ gas is more practical and cost-efficient.

There are two kinds of approaches when using tracer gas: the static method and the dynamic method. Bot (1983) used the static method or continuous injection; Baptista et al., 1999; Fernandez and Bailey (1993), and Boulard and Draoui (1995), injected gas at a constant rate into a greenhouse until an equilibrium concentration was reached. The gas supply and sampling system must be distributed around the greenhouse to obtain good dispersion of the gas and uniform sampling of the air. Unfortunately, this method requires a high consumption of tracer gas.

In contrast, the dynamic method, or pulse injection, uses less tracer gas to estimate the ventilation rate. This method is known as the decay rate method because it measures the decay rate of a tracer gas concentration from an initial level. This method has been used by Nederhoff and Vegter (1994), Fernandez and Bailey (1992), Baptista et al. (1999), Muñoz et al. (1999), and Kuroyanagi et al. (2014). The tracer gas was injected and uniformly distributed in the greenhouse until a specific pre-determined concentration was reached. The decay rate in the gas concentration was then measured. When $\mathrm{CO}_{2}$ concentration level had decreased to $10-20 \%$ of the initial value, another pulse of gas was injected, and the decay was measured. The ventilation rate $(G)$ can be calculated from the following equation (Nederhoff et al., 1985):

$$
N=\frac{3600}{t_{1}} \ln \left[\frac{C_{\text {in }}\left(t_{0}\right)-C_{\text {out }}}{C_{\text {in }}\left(t_{1}\right)-C_{\text {out }}}\right]
$$

Assuming that $G$ and $C_{\text {out }}$ are constant over the observed time interval, in which $C_{\text {in }}\left(t_{0}\right)$ is the initial $\mathrm{CO}_{2}$ concentration at $t=0, C_{i n}\left(t_{1}\right)$ is the $\mathrm{CO}_{2}$ concentration measured at $t=t_{1}$, and the factor 3600 is introduced because the ventilation rate is defined in $\mathrm{h}^{-1}$ and $t$ in seconds. $N$ is the greenhouse air exchange rate expressed as times per hour of exchange of the greenhouse volume $\left(\mathrm{h}^{-1}\right)$. The greenhouse air exchange rate per hour $(N)$ can be converted to the ventilation rate value, $G\left(\mathrm{~m}^{3} \mathrm{~m}^{-2} \mathrm{~min}^{-1}\right)$ as follows:

$$
G=\frac{1}{60} \frac{N V_{g}}{A_{f}}
$$

where, $V_{g}$ is the greenhouse volume $\left(\mathrm{m}^{3}\right)$, and $A_{f}$ is the greenhouse floor area $\left(\mathrm{m}^{2}\right)$.

For accurate ventilation rate values based on the decay rate method with $\mathrm{CO}_{2}$, Nederhoff et al. (1985) suggested supplying $\mathrm{CO}_{2}$ when the concentration fell to $1000 \mu \mathrm{mol} \mathrm{mol}^{-1}$. $\mathrm{CO}_{2}$ was injected up to $2000 \mu \mathrm{mol} \mathrm{mol}^{-1}$, because at concentrations between 1000 and $2000 \mu \mathrm{mol} \mathrm{mol}^{-1}, \mathrm{CO}_{2}$ concentration has little effect on photosynthesis; and, for accurate measurements, the concentration of the tracer gas inside the greenhouse must be significantly higher than that in the outside environment $\left( \pm 330 \mu \mathrm{mol} \mathrm{mol}^{-1}\right)$.

Results from the tracer gas technique in closed or low-level ventilation was in agreement with other methods for estimating the ventilation rate, as mentioned by Katsoulas et al. (2006) and Boulard and Draoui (1995) (Table $3)$. At the leakage rate condition, the ventilation rate via the tracer gas method was comparable with that using IRGA 
and the theoretical model (pressure difference and wind pressure model), as shown in Table 3 . However, there is little research about applying this technique to a maximum ventilation open area, such as that during summer. Therefore, it is better to reduce the $\mathrm{CO}_{2}$ concentration enrichment strategy in a maximum ventilation opening area, but it is still sufficient to predict the ventilation rate based on the decay rate approach.

There are two ways to predict the ventilation rate based on the heat balance method, that used by Katsoulas et al. (2006) and Yasutake et al. (2017), and the water vapor balance technique by Boulard and Draoui (1995). Both methods have good results, although the accuracy is slightly less than that with tracer gas, at a window aperture range of $0-20 \%$. A correlation between tracer gas and heat balance under opening vents between $0-20 \%$ was weak because the ventilation rate value fairly deviated from the target line which the heat balance value was higher than the tracer gas value (Yasutake et al., 2017). In contrast, the water vapor balance method had a slightly higher gradient value than that of the continuous and decay rate methods. This may be due to the estimation of plant transpiration from a limited number of plants (Boulard and Draoui, 1995).

Overall, tracer gas is the most widely used ventilation measurement method in conjunction with either the constant flow or the decay rate. Many authors have shown that the tracer gas at leakage and low ventilation conditions showed excellent performance; however, there is a lack of information on applications under maximum ventilation conditions, such as in summer.

In summer, ventilation removes energy and prevents excessively high temperatures. The tracer gas presented numerous disadvantages in large-scale greenhouses (Demrati et al., 2001), and the mixing problem was a primary potential source of error when the tracer gas method was used. This problem is particularly significant when a large area and low natural ventilation rate is used, because when there is large opening, it can be challenging to get the right mixing gas. This will affect an increase in operational costs for gas consumption. Simultaneously, the tracer gas consumption method results in a considerably inefficient use of gases when the window aperture is too large. Therefore, it needs to be determined how large the opening of the ventilation can be, to still predict the air exchange rate accurately using the tracer gas approach. It is necessary to conduct and evaluate the application of the tracer at maximum level ventilation conditions under both roof and side vent configurations. Moreover, it should be compared with other methods comprehensively, such as the heat balance and water vapor balance method. 
Please cite this article as

Tusi and Shimazu. Reviews in Agricultural Science, 8: 279-299, 2020

https://dx.doi.org/10.7831/ras.8.0_279

Table 3: Application of tracer gas in different window apertures

\begin{tabular}{|c|c|c|c|c|c|c|c|}
\hline $\begin{array}{l}\text { Tracer } \\
\text { gas }\end{array}$ & $\begin{array}{l}\text { Comparative } \\
\text { method }\end{array}$ & $r^{*}$ & Greenhouse type & $\begin{array}{l}\text { Opening } \\
\text { window } \\
(W, \%)\end{array}$ & $\begin{array}{l}N \\
\left(\mathrm{~h}^{-1}\right)\end{array}$ & $\begin{array}{l}G \\
\left(\mathrm{~m}^{3} \mathrm{~m}^{-2} \mathrm{~min}^{-1}\right)\end{array}$ & Source \\
\hline $\mathrm{N}_{2} \mathrm{O}$ & $\begin{array}{l}\text { Decay Rate } \\
\text { Pressure } \\
\text { difference }\end{array}$ & 0.82 & $\begin{array}{l}\text { Four-spans Glasshouse } \\
\left(A_{f}, 12.8 \times 16.0 \mathrm{~m}^{2}\right) \\
\text { Roof }(\text { leeside }) \text { vent } \\
\left(\max .42^{\circ}\right)\end{array}$ & $\begin{array}{l}0 \%{ }^{\mathrm{b}} \\
10 \%^{\mathrm{b}} \\
20 \%{ }^{\mathrm{b}}\end{array}$ & $\begin{array}{l}0.33-0.53 \\
7.78-19.43 \\
16.14-37.37 \\
\left(1-5 \mathrm{~m} \mathrm{~s}^{-1}\right)\end{array}$ & $\begin{array}{l}0.025-0.116 \\
0.590-1.474 \\
1.224-2.835\end{array}$ & $\begin{array}{l}\text { Baptista et } \\
\text { al. (1999) }\end{array}$ \\
\hline $\mathrm{N}_{2} \mathrm{O}$ & $\begin{array}{l}\text { Decay Rate } \\
\text { Energy } \\
\text { balance }\end{array}$ & 0.86 & $\begin{array}{l}\text { Single-span of arch- } \\
\text { shaped roof } \\
\left(A_{f}, 8 \times 20 \mathrm{~m}^{2}\right) \\
\text { Side and roof vents with } \\
\text { the screen }(50 \% \\
\text { porosity) }\end{array}$ & $\begin{array}{l}0 \% \mathrm{~d} \\
\text { no screen } \\
0 \% \\
\text { With screen } \\
11.2 \%{ }^{\mathrm{d}} \\
\text { roof } \\
17.0 \%{ }^{\mathrm{d}} \\
\text { side } \\
28.2 \%{ }^{\mathrm{d}} \\
\text { Roof and side }\end{array}$ & $\begin{array}{l}2.97-7.73 \\
6.39-19.64 \\
15.73-56.52\end{array}$ & $\begin{array}{l}0.177-0.461 \\
0.381-1.170 \\
0.938-3.368\end{array}$ & $\begin{array}{l}\text { Katsoulas et } \\
\text { al. (2006) }\end{array}$ \\
\hline $\mathrm{N}_{2} \mathrm{O}$ & $\begin{array}{l}\text { Decay rate } \\
\text { Theoretical } \\
\text { model (wind } \\
\text { pressure) }\end{array}$ & 0.93 & $\begin{array}{l}\text { Three-span tunnel-type } \\
\text { greenhouse } \\
\left(A_{f}, 19.2 \times 12 \mathrm{~m}^{2}\right) \\
\text { Roof vents with screen } \\
45 \%)\end{array}$ & $\begin{array}{l}9.4 \%{ }^{\mathrm{d}} \\
(0.6 \mathrm{~m})\end{array}$ & $5.43-36.18$ & $0.226-1.508$ & $\begin{array}{l}\text { Muñoz et al. } \\
\text { (1999) }\end{array}$ \\
\hline $\begin{array}{l}\mathrm{N}_{2} \mathrm{O} \\
\mathrm{CO}_{2}\end{array}$ & $\begin{array}{l}\text { Decay rate } \\
\left(\mathrm{N}_{2} \mathrm{O}\right) \\
\text { Continuous } \\
\text { injection } \\
\left(\mathrm{CO}_{2}\right) \\
\text { Water vapor } \\
\text { balance }\end{array}$ & $\begin{array}{l}0.68 \\
0.68 \\
0.60\end{array}$ & $\begin{array}{l}\text { Two-span type } \\
\text { greenhouse (Filclair) } \\
\left(A_{f}, 2 \times 6.5 \mathrm{~m} \times 32 \mathrm{~m}\right)\end{array}$ & $\begin{array}{l}0 \% \\
8 \%\end{array}$ & $\begin{array}{l}0.004-0.04 \\
0.12-0.15\end{array}$ & $\begin{array}{l}0.0003-0.002 \\
0.007-0.588\end{array}$ & $\begin{array}{l}\text { Boulard and } \\
\text { Draoui } \\
(1995)\end{array}$ \\
\hline $\mathrm{CO}_{2}$ & $\begin{array}{l}\text { Decay rate } \\
\text { IRGA device }\end{array}$ & $\begin{array}{l}0.9 \\
( \pm 1 \%)\end{array}$ & $\begin{array}{l}\text { Venlo type } \\
\left(A_{f}, 6 \times 9.6 \mathrm{~m}^{2}\right) \\
\text { Roof (leeside) vent } \\
\text { (max. } 0.6 \mathrm{~m}):\end{array}$ & $\begin{array}{l}0 \%{ }^{\mathrm{a}} \\
14 \% \%^{\mathrm{a}}\end{array}$ & $\begin{array}{l}0.25-0.50 \\
2.70-4.80 \\
\left(2-4 \mathrm{~m} \mathrm{~s}^{-1}\right)\end{array}$ & $\begin{array}{l}0.012-0.023 \\
0.127-0.227\end{array}$ & $\begin{array}{l}\text { Nederhoff et } \\
\text { al. (1985) }\end{array}$ \\
\hline $\mathrm{CO}_{2}$ & $\begin{array}{l}\mathrm{CO}_{2} \text { balance } \\
\text { Energy } \\
\text { balance }\end{array}$ & 0.39 & $\begin{array}{l}\text { Single-span } \\
\left(A f, 7.5 \times 20 \mathrm{~m}^{2}\right) \\
\text { side and roof vents }\end{array}$ & $\begin{array}{l}0 \%{ }^{\mathrm{c}} \\
20 \%{ }^{\mathrm{c}}\end{array}$ & $\begin{array}{l}<=0.50 \\
6.00-7.50 \\
\left(2-4 \mathrm{~m} \mathrm{~s}^{-1}\right)\end{array}$ & $\begin{array}{l}<=0.026 \\
0.312-0.390\end{array}$ & $\begin{array}{l}\text { Yasutake } e t \\
\text { al. (2017) }\end{array}$ \\
\hline $\mathrm{SF}_{6}$ & None & - & $\begin{array}{l}\text { Two spans of arch- } \\
\text { shaped roof } \\
\left(A_{f}, 9.7 \times 18.4 \mathrm{~m}^{2}\right)\end{array}$ & $0 \%$ & $\begin{array}{l}0.27-0.46 \\
\left(2-4 \mathrm{~m} \mathrm{~s}^{-1}\right)\end{array}$ & $0.021-0.035$ & $\begin{array}{l}\text { Kuroyanagi } \\
\text { et al. }(2014)\end{array}$ \\
\hline $\begin{array}{l}\text { Averag } \\
\text { Averag }\end{array}$ & $\begin{array}{l}\text { value at close } \\
\text { value at close }\end{array}$ & $\begin{array}{l}\text { tilation } \\
\text { tilation }\end{array}$ & $\begin{array}{l}\text { wind speed } 1-2 \mathrm{~m} \mathrm{~s}^{-1} \\
\text { wind speed } 4-5 \mathrm{~m} \mathrm{~s}^{-1}\end{array}$ & $\begin{array}{l}0 \% \\
0 \%\end{array}$ & $\begin{array}{l}0.37 \pm 0.12 \\
0.81 \pm 0.29\end{array}$ & $\begin{array}{l}0.023 \pm 0.007 \\
0.051 \pm 0.020\end{array}$ & \\
\hline
\end{tabular}

Note: *The Pearson correlation coefficient for tracer gas and comparative method; a) percentage opening of maximum opening (0.6 $\mathrm{m})$; b) the ventilator aperture is expressed as a percentage of the maximum aperture $\left(42^{\circ}\right)$; c) the opening area is presented as the ratio of the coverage area to the window opening; and d) total opening area per greenhouse floor area. 


\subsection{Heat balance method}

The heat balance method was developed using microclimate data. Some models concentrated on a naturally ventilated greenhouse with a small opening on the roof or on both roof and side configurations. The predicted model was validated with the experimental data, and the result was fitted between them (Table 4) (Fernandez and Bailey, 1992; Katsoulas et al., 2006; Yasutake et al., 2017).

The heat balance method uses either static or dynamic models (Roy et al., 2002). The dynamic model is more accurate than that is the static model, because the latter looks at only a few parameters. Several dynamic models have been developed (Teitel and Tanny, 1999; Wang and Boulard, 2000; Roy et al., 2002). The greenhouse heat balance is the sum of the gains and losses during a specified period. This method assumes a steady state and uses energy conservation technique, i.e., heat gains are equal to heat losses. The energy content is affected by heat gains and losses, determined by the change in temperature. The heat exchange between the inside and outside of a greenhouse is a complex mechanism involving the processes of radiation, conduction, convection, and latent heat.

Fernandez and Bailey (1992) developed a model based on solar energy, considering the stored energy inside the greenhouse that involved the cover, inside air, crop, and soil. Demrati et al. (2001) proposed a model based on a global energy balance of the greenhouse. They considered all parameters involved in the heat transfer processes occurring in the greenhouse. For instance, with net solar radiation as the input heat flux, and heat fluxes through the soil, material cover, and ventilation system as heat loss, the following equation is used to estimate the ventilation rate:

$$
\begin{aligned}
& G=\frac{A_{f}\left(R_{n}-F_{s}\right)-A_{c}\left[K \Delta T+C_{h} \Delta T_{c}\right]}{\rho_{a}\left[c_{p} \Delta T+L \Delta H_{A}\right]} \\
& K=a+b v \\
& C_{h}=1.75\left(T_{c}-T_{i n}\right)^{0.333}
\end{aligned}
$$

where $G$ is the volume flow rate $\left(\mathrm{m}^{3} \mathrm{~s}^{-1}\right) ; A_{f}$ and $A_{c}$ are the greenhouse floor and cover area $\left(\mathrm{m}^{2}\right) ; R_{n}$ is the net radiation $\left(\mathrm{W} \mathrm{m}^{-2}\right) ; F_{s}$ is the thermal flux at soil surface $\left(\mathrm{W} \mathrm{m}^{-2}\right) ; K$ is the global sensible heat loss coefficient through the greenhouse material cover $\left(\mathrm{W} \mathrm{m}^{-2} \mathrm{~K}^{-1}\right) ; \Delta T$ is the air temperature difference between inside and outside $\left({ }^{\circ} \mathrm{C}\right) ; A_{\mathrm{c}}$ is the surface area of the roof $\left(\mathrm{m}^{2}\right) ; C_{h}$ is the convective heat exchange coefficient between inside air and the material cover $\left(\mathrm{W} \mathrm{m}^{-2} \mathrm{~K}^{-1}\right) ; \Delta T_{c}$ is the temperature difference between inside air temperature $\left(T_{i n}\right)$ and the material cover $\left(T_{c}\right)$ $\left({ }^{\circ} \mathrm{C}\right) ; \rho_{a}$ is the air density $\left(\mathrm{kg} \mathrm{m}^{-3}\right) ; c_{p}$ is the air specific heat at constant pressure $\left(\mathrm{J} \mathrm{kg}^{-1} \mathrm{~K}^{-1}\right) ; L$ is the latent heat of water vaporization $\left(\mathrm{J} \mathrm{kg}^{-1}\right) ; \Delta H_{A}$ is the absolute humidity difference between inside and outside air $\left(\mathrm{kg} \mathrm{kg}^{-1}\right) ; v$ is the wind speed ( $\mathrm{m} \mathrm{s}^{-1}$ ), and $a$ and $b$ are constants. Demrati et al. (2001) used constant values for a of $1.44 \mathrm{~W} \mathrm{~m}^{-2} \mathrm{~K}^{-1}$ and $b$ of $0.12 \mathrm{~J} \mathrm{~m}^{-2} \mathrm{~K}^{-1}$, when considering the greenhouse floor area surface as the surface unit.

The ventilation rate value prediction is affected by the dimensions and type of greenhouse. A multi-spans-type greenhouse has a higher value than a single-type greenhouse (Figure 4 and Table 4). Large-scale greenhouses (Figure 4b) have more natural ventilation than the small-scale single-span greenhouse type (Figure 4a), even if the outdoor wind speed is the same. The ratio of the side and roof vents to the floor area $(W \%)$ of the larger-scale greenhouse became smaller even when the vents were widened. However, the small greenhouse had a larger $W$, but the air exchange rate was low because of the effect of temperature difference ventilation from the side vents to the skylight. Therefore, it was necessary to enlarge the window aperture and force ventilation. 
Table 4: The heat balance method performance under a different type of greenhouse and window apertures

\begin{tabular}{|c|c|c|c|c|c|c|c|}
\hline Greenhouse Type & $\begin{array}{c}\text { Comparative } \\
\text { method }\end{array}$ & $\begin{array}{c}\text { Vents } \\
\text { configuration }\end{array}$ & $\begin{array}{l}\text { Window } \\
\text { aperture }\end{array}$ & $\begin{array}{l}W^{\mathrm{c}} \\
(\%)\end{array}$ & $\begin{array}{c}N \\
\left(\mathrm{~h}^{-1}\right)\end{array}$ & $R^{2 \mathrm{~d}}$ & Sources \\
\hline $\begin{array}{l}\text { Multispan (4 spans) } \\
\left(A_{f}=12.8 \times 33 \mathrm{~m}^{2} ; V_{g}=1,523\right. \\
\left.\mathrm{m}^{3}\right)^{\mathrm{a}}\end{array}$ & $\begin{array}{l}\text { Tracer Gas } \\
\left(\mathrm{N}_{2} \mathrm{O}\right)\end{array}$ & Flap Roof & $\begin{array}{l}0 \%\left(0^{\circ}\right)^{\mathrm{b}} \\
10 \%\left(3.9^{\circ}\right) \\
20 \%\left(7.8^{\circ}\right) \\
30 \%\left(11.6^{\circ}\right) \\
40 \%\left(15.4^{\circ}\right)\end{array}$ & $\begin{array}{l}0 \\
2 \\
5 \\
7 \\
10\end{array}$ & $\begin{array}{l}0.8 \\
3.2 \\
4.8 \\
6.4 \\
7.4 \\
\end{array}$ & $\begin{array}{l}0.06 \\
0.47 \\
0.32 \\
0.41 \\
0.81 \\
\end{array}$ & $\begin{array}{l}\text { Fernandez and } \\
\text { Bailey (1992) }\end{array}$ \\
\hline $\begin{array}{l}\text { Large multi-span Canarian } \\
\text { type greenhouse } \\
\left(A_{f}=10,000 \mathrm{~m}^{2} ; 6-7 \mathrm{~m}\right. \\
\text { height) }\end{array}$ & $\begin{array}{l}\text { Theoretical } \\
\text { model } \\
\text { (wind and } \\
\text { stack effect) }\end{array}$ & $\begin{array}{l}\text { Both roof and } \\
\text { side vents }\end{array}$ & $9 \%$ & 9 & 9.8 & 0.86 & $\begin{array}{l}\text { Demrati et al. } \\
(2001)\end{array}$ \\
\hline $\begin{array}{l}\text { Single-span plastic } \\
\text { greenhouse } \\
\left(A_{f}=150 \mathrm{~m}^{2} ; V_{g}=468.2 \mathrm{~m}^{3}\right)\end{array}$ & $\begin{array}{l}\text { Tracer gas } \\
\left(\mathrm{CO}_{2} \text { balance }\right)\end{array}$ & $\begin{array}{l}\text { Both side and } \\
\text { roof }\end{array}$ & $\begin{array}{l}0 \% \\
20 \%\end{array}$ & $\begin{array}{l}0 \\
40\end{array}$ & $\begin{array}{l}1.9 \\
3.8\end{array}$ & $\begin{array}{l}0.39 \\
0.39\end{array}$ & $\begin{array}{l}\text { Yasutake et al., } \\
(2017)\end{array}$ \\
\hline $\begin{array}{l}\text { Single-span plastic } \\
\text { greenhouse } \\
\left(A_{f}=160 \mathrm{~m}^{2} ; V_{g}=572 \mathrm{~m}^{3}\right)\end{array}$ & $\begin{array}{l}\text { Tracer gas } \\
\left(\mathrm{N}_{2} \mathrm{O}\right)\end{array}$ & $\begin{array}{l}\text { Closed } \\
\text { Side only } \\
\text { Roof } \\
\text { Roof and Side }\end{array}$ & $\begin{array}{l}0 \% \\
17 \% \\
11 \% \\
28.2 \% \\
\end{array}$ & $\begin{array}{l}0 \\
17 \\
11 \\
28\end{array}$ & $\begin{array}{l}0.5 \\
1.7 \\
2.5 \\
2.6\end{array}$ & 0.76 & $\begin{array}{l}\text { Katsoulas et al. } \\
(2006)\end{array}$ \\
\hline
\end{tabular}

Note: a) $A_{f}$ is the greenhouse floor area, $V_{g}$ is the greenhouse volume, b) the percentage of window aperture based on ratio angle of opening and maximum angle of the opening ventilator; c) $W$ is window aperture in \%. It was calculated based on the ratio between the total opening area and the greenhouse floor area, and d) $R^{2}$ is the coefficient of determination (R-squared).

Figure 5 shows that the correlation value of the air exchange rate between the heat balance method and the tracer gas method (using $\mathrm{N}_{2} \mathrm{O}$ ) increased linearly with the enlargement of the roof vents in the large-scale greenhouse. Fernandez and Bailey (1992) noted that measurement precision increased with the length of the measurement time scale and vent opening. For higher ventilation conditions, it was found that the energy balance gives better results for larger ventilator apertures (Fernandez and Bailey, 1992; Baptista et al., 2001).

However, the R-squared values presented the strength of the relationship between the estimated air exchange rate via the heat balance method and the measured tracer gas using $\mathrm{N}_{2} \mathrm{O}$, indicating a weak correlation at below $10 \%$ of the window aperture. This was also found in a small-scale greenhouse, as mentioned by Yasutake et al. (2017). Fernandez and Bailey (1992) elucidated that a significant error occurred when the window condition was closed or there was a leakage rate condition, and this was caused by an error in other components of the energy balance method compared to the energy lost by ventilation. Therefore, it is challenging to correlate measurement and prediction with heat balance in the closed window condition or the smallest opening area (angles).

It is evident that the heat balance method can be used to predict the ventilation rate under a small window aperture. It should be determined what the minimum solar radiation and window opening levels would be that could still allow for a reasonable prediction of the air exchange rate. Further study is needed on the heat balance method, especially in the lower ventilation rate conditions.

Several authors calculated the air exchange rate using the heat balance method with daily measurement data (Demrati et al., 2001; Harmanto et al., 2006a) and found good prediction values. One of the goals of monitoring the ventilation rate is to monitor the photosynthetic rate. As explained before, continuous monitoring of photosynthesis should be employed in a short-term interval. 

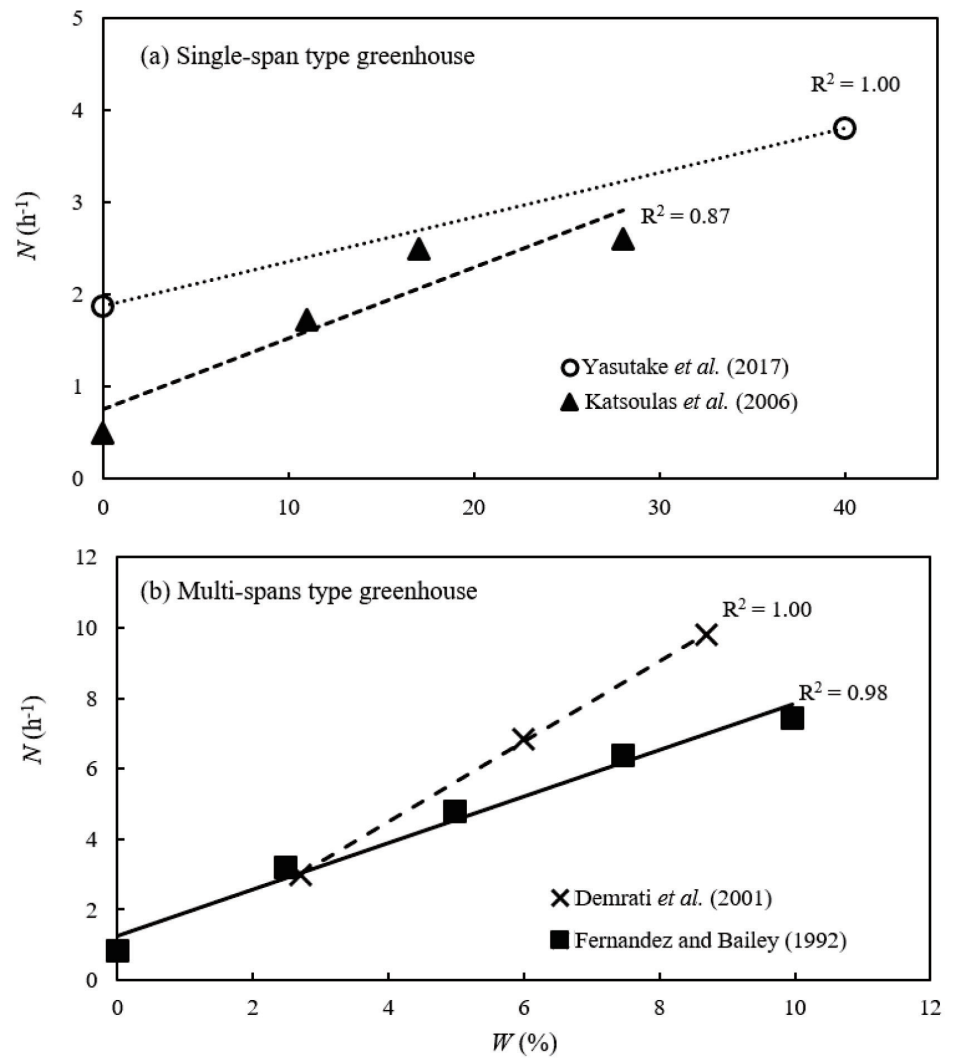

Figure 4: Single-span and multi-spans greenhouse air exchange rate $(N)$ value under different window apertures $(W)$ (the ratio between total opening areas with greenhouse floor area)

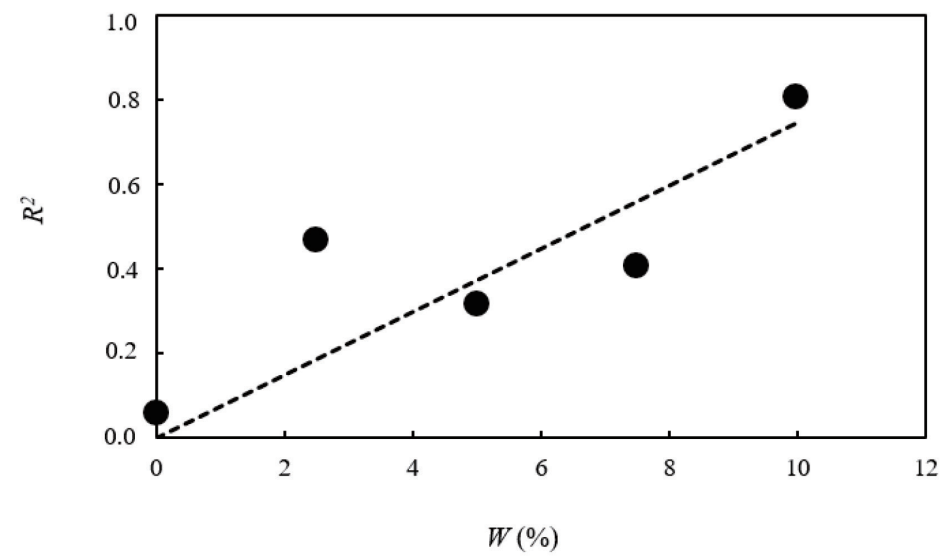

Figure 5: R-squared explains the strength of the relationship between the predicted air exchange rate via the heat balance method and the measured value by tracer gas method using $\mathrm{N}_{2} \mathrm{O}$ at multi-span greenhouse (4 spans) under different of window apertures $(W)$. The greenhouse floor area was $422 \mathrm{~m}^{2}$ and roof vents were applicable (Fernandez and Bailey, 1992). 
Yasutake et al. (2017) found that a single-span type greenhouse with a ventilation opening area up to $20 \%$ of the total opening area resulted in a ventilation rate of below four air exchanges per hour. However, the coefficient of determination value was low $\left(R^{2}=0.39\right)$ compared with the Katsoulas et al. (2006) predicted value $\left(R^{2}=0.76\right)$. Additionally, at leakage or the smallest opening area, the predicted value of Katsoulas et al. (2006) was more accurate than that by Yasutake et al. (2017).

The accuracy of different results between the two studies, Katsoulas et al. (2006) and Yasutake et al. (2017), might be affected by the ventilation rate methods used. Yasutake et al. (2017) conducted tracer gas using $\mathrm{CO}_{2}$ with the $\mathrm{K} 30$ engine sensor and Katsoulas et al. (2006) used $\mathrm{N}_{2} \mathrm{O}$ with an IRGA. Moreover, the predicted value conducted by Katsoulas et al. (2006) used the heat balance method proposed by Demrati et al. (2001). In contrast, Demrati et al. (2001) and Katsoulas et al. (2006) considered all parameters involved in the heat transfer processes occurring in the greenhouse. Hence, it is better to consider all parameters of heat transfer when using the heat balance approach to compute the ventilation rate. Further experiments are needed on the heat balance method under the different opening areas, from leakage rate condition to a maximum opening area of the ventilation system, and in different light intensities (or seasons).

\subsection{Water vapor balance}

The water vapor balance method is a quick and straightforward method to estimate the ventilation rate in a greenhouse. This method uses water vapor from the evapotranspiration process and air-specific humidity in the greenhouse. Many authors have neglected soil evaporation due to the presence of continuous plastic mulch on the soil surface or soilless culture (hydroponic systems) as well as condensation within the greenhouse. The following equation is used to estimate the ventilation rate (Boulard and Draoui, 1995):

$$
\rho V_{g} \frac{d p_{\text {in }}}{d t}=\rho G(t)\left[p_{\text {out }}(t)-p_{\text {in }}(t)\right]+E T(t)
$$

Here, $\rho$ is air density $\left(\mathrm{kg} \mathrm{m}^{-3}\right), p_{\text {in }}$ and $p_{\text {out }}$ are absolute humidity $\left(\mathrm{kg} \mathrm{kg}^{-1}\right)$, and $E T$ is evapotranspiration rate $(\mathrm{kg}$ $\mathrm{s}^{-1}$ ). All the measurements were automatically recorded each minute, and averaged over $1 \mathrm{~h}$, then the above equation was used to calculate $G$ and $N$ as a simple function of $p_{i n}, p_{\text {out }}$, and $E T$.

This method was previously adopted by Boulard and Draoui (1995) in a two-span plastic naturally ventilated greenhouse with roof vents only. The water vapor balance method was in good agreement with other methods using tracer gas, that is, $\mathrm{CO}_{2}$ or $\mathrm{N}_{2} \mathrm{O}$. Harmanto et al. (2006b) pointed out that the water vapor balance method had a better estimation accuracy when measured in a greenhouse cultivated with mature plants and with a smaller ventilation opening area. Table 5 shows that the method has been applied in various types of compartments with good results, such as multi-span greenhouses with continuous roof vents only (Boulard and Draoui, 1995; Kittas et al., 2002), those with continuous roof and side vent configurations (Mashonjowa et al., 2010), units with a screen house (Harmanto et al., 2006b; Rigakis et al., 2015), and compartments with growth chambers (Li et al., 2012).

Figure 6 illustrates the performance of the water vapor balance method for predicting the air exchange rate $(N)$ in a greenhouse cultivated with tomato plants. Mainly large-scale greenhouses with multiple spans are shown, except for one source from Harmanto et al. (2006b) which uses screen houses. In general, it is clear that the ventilation rate increases with the width of the window opening $(W)$. Most of the results in this graph were measured under small opening conditions $(<10 \%$ of $W$ ) or ventilation rates below 20 air exchange rates per hour in multi-span greenhouses equipped with vents, both on the sides and/or above only. 
Information on the performance of the water vapor balance method is quite limited under maximum opening ventilation conditions. Further studies are needed to evaluate the ventilation performance of single-span type greenhouses with varying window apertures.

There are some disadvantages of the water vapor balance method, for instance the overestimation of ventilation rate at night, and errors in scaling-up crop transpiration from a single plant (or a few plants) to whole canopy transpiration (Boulard and Draoui, 1995; Mashonjowa et al., 2010). An increase in the transpiration error might be present due to the sensor used in the research. The transpiration rate was measured using a stem heat balance sensor (sap flow gauges) installed on the main stems of the crops. This sensor is handy, although sap-flow is not precisely the same as transpiration, and it requires non-ideal calibration (Akutsu et al., 2015). In addition, Kittas et al. (2002) noted error values because of either direct solar radiation penetration to the lysimeter by the window opening or from temporary shading of the lysimeter by the greenhouse frame.

Overall, the ventilation rate using the water vapor balance method on the mature plant has a good prediction value; however, it is challenging to predict the rate for young plants, possibly due to the error of crop transpiration rate caused by small plants, or less uniformity of humidity in the greenhouse (Harmanto et al., 2006b).

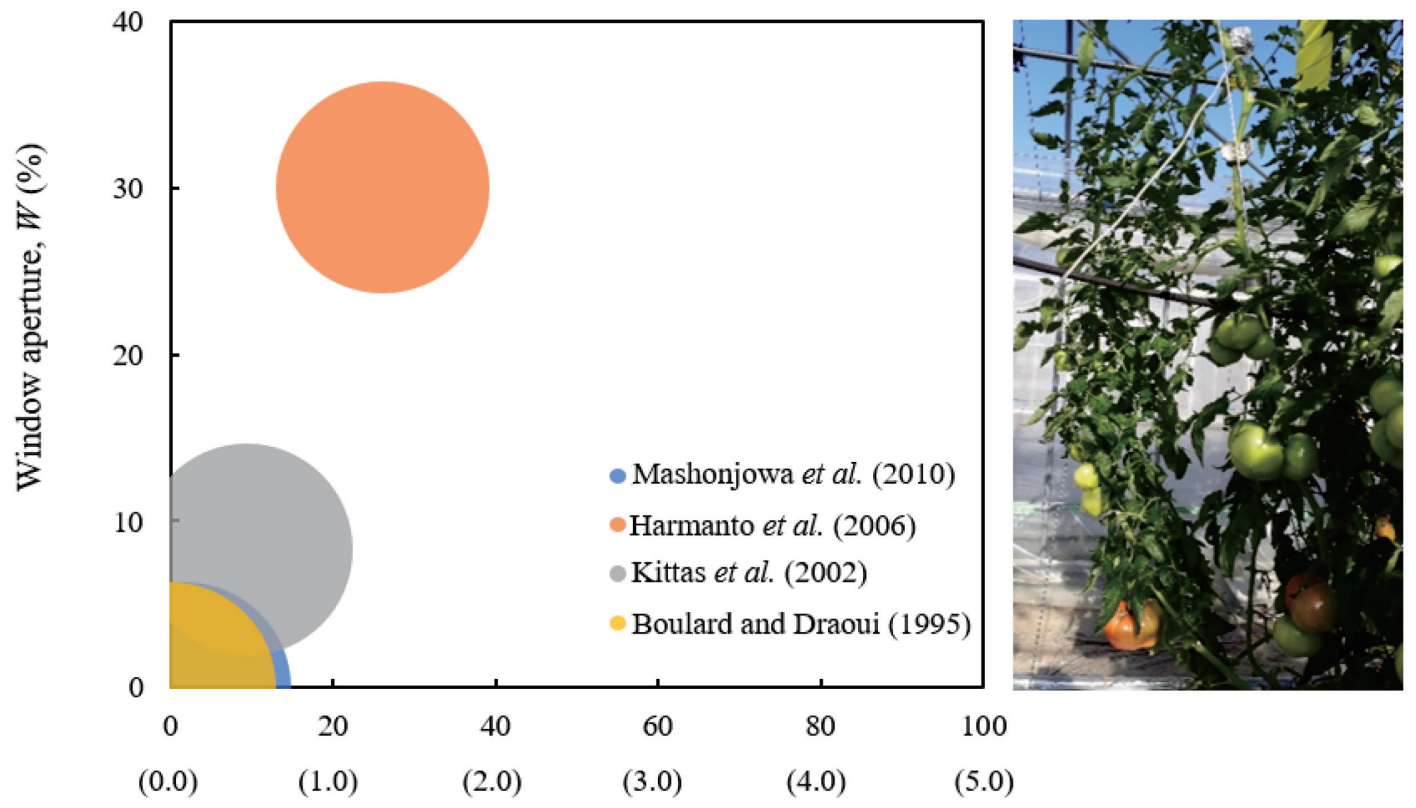

Air exchange rate, $N\left(\mathrm{~h}^{-1}\right)$

(ventilation rate, $G, \mathrm{~m}^{3} \mathrm{~m}^{-2} \mathrm{~min}^{-1}$ )

Figure 6: Bubble scattered chart of the air exchange rate using water vapor balance method in a single-span and multi-span greenhouse type cultivated with tomato crops

The water vapor balance was mainly affected by transpiration, which is determined by environmental factors, mainly radiation, vapor deficit (Jolliet and Bailey, 1992; Katsoulas et al., 2001), and air velocity (Jolliet and Bailey, 1992; Thongbai et al., 2010). Transpiration from leaves is regulated by stomatal conductance $\left(G_{s}\right)$. The $G_{s}$ are determined by the water potential in the plant, which depends on the balance between root water absorption and 
transpiration. Since stomata also mediate $\mathrm{CO}_{2}$ diffusion into the leaves, maintaining a low VPD $(0.39-0.40 \mathrm{kPa})$ could manage the $G_{s}$ to the optimum value and improve the effect of $\mathrm{CO}_{2}$ fertilization between 350-1000 $\mu \mathrm{mol} \mathrm{mol}^{-}$ ${ }^{1}$, as reported by Zabri and Burrage (1998). Thongbai et al. (2010) considered that an increase in $\mathrm{CO}_{2}$ concentration up to the outside concentration $\left(350-450 \mu \mathrm{mol} \mathrm{mol}^{-1}\right)$ and/or air circulation in a ventilated greenhouse $\left(1 \mathrm{~m} \mathrm{~s}^{-1}\right)$ could increase the net photosynthetic rate significantly and maintain the transpiration processes. Therefore, it is essential to keep the inside greenhouse climate at optimum conditions for the crops, especially keeping the vapor pressure deficit parameter at optimum conditions because it can improve the photosynthesis and transpiration processes under $\mathrm{CO}_{2}$ application.

Continuous crop transpiration measurement information is essential not only for the need to know the condition of the plants and the whole greenhouse condition, but also for estimating the ventilation rate using the water vapor balance approach. Various devices have been applied for measuring transpiration, such as an electronic scale, a sap flow sensor, and a flow meter, as presented in Table 5. A weigh scale minimizes the errors of scaling up from a few plants to the whole canopy transpiration, and permits the use of water flow measurement in the greenhouse. Akutsu et al. (2015) conducted a direct transpiration measurement on a tomato crop stand using artificial leaves made of towel and paper filters. The report showed agreement with data measured by a weighing device.

In the context of ventilation rate monitoring using the water vapor balance technique, an electronic weighing device was most commonly used by researchers, followed by sap flow measurements. The weighing method has reasonably good accuracy (Leperen and Madery, 1994) but is expensive for the growers, is measured only on some plants, and does not have the ability to describe the entire transpiration rate in the greenhouse. It needs to be determined how to measure and monitor transpiration in a greenhouse continuously. Further study is also required to validate the weight and sap flow measurements that are applied to one or several plants for the calculation of the overall transpiration rate of plants in the greenhouse.

\section{Conclusions and future work}

The $\mathrm{CO}_{2}$ balance method for a greenhouse is applied to the photosynthetic rate of the plant canopy by accurately measuring the ventilation rate and the difference between internal and external $\mathrm{CO}_{2}$ concentrations. The reliability of $\mathrm{CO}_{2}$ concentration control depends on the measurement error of the $\mathrm{CO}_{2}$ sensor and the operating characteristics of the $\mathrm{CO}_{2}$ supply device, which consists of a porous tube, flow meter, valve, and cylinder. The ventilation rate changes depend on the climatic conditions and window apertures, and it is necessary to continuously measure the, rate by the tracer gas method, the heat balance method, or the water vapor balance method for application to the $\mathrm{CO}_{2}$ balance method.

The tracer gas method is highly reliable as a ventilation rate measurement method, but a large amount of tracer gas is required for use in a greenhouse with a large ventilation volume for long-term measurement. In particular, $\mathrm{CO}_{2}$ gas is not suitable as a tracer gas for ventilation in a greenhouse. Therefore, the evaluation of greenhouse ventilation using alternative methods (heat balance and water vapor balance methods) should be conducted to estimate the photosynthetic rate using the $\mathrm{CO}_{2}$ balance method under various window apertures, and compare then with the tracer gas method. 


\section{Acknowledgments}

The first author would like to acknowledge the Indonesia Endowment Fund for Education (Lembaga Pengelola

Dana Pendidikan-PDP) under the Beasiswa Unggulan Dosen Indonesia-Luar Negeri (BUDI-LN) batch 2017, Ministry of Finance, the Republic of Indonesia, for its scholarship funding support.

\section{REFERENCES}

Acock, B, Charles-Edwards DA, Fitter DJ, Hand DW, Ludwig LJ, Warren Wilson J, and Withers AC (1978) The contribution of leaves from different levels within a tomato crop to canopy net photosynthesis: an experiment examination of two canopy models. J. Exp. Bot., 29: 815-827.

Akutsu M, Sunagawa H, Usui T, Tamaki M, Taniai N, Hirata M, and Takakura T (2015) Non-destructive, real-time, and automatic measurement of transpiration from a plant canopy stand. J. Adv. Agric., 5: 677-683.

Albert B, Le Quillec S, Lesourd D, Loda D, Barette R, and Brajeul E (2017) Finding optimal temperatures to maximize leaf photosynthesis in a tomato or cucumber crop in heated glasshouse. Acta. Hort., 1170: 317-320.

Baptista FJ, Bailey BJ, Randall JM, and Meneses JF (1999) Greenhouse ventilation rate: theory and measurement with tracer gas techniques. J. Agric. Eng. Res., 72: 363-374.

Baptista FJ, Bailey BJ, and Meneses JF (2001) Natural ventilation of greenhouses. Comparison of measured and predicted ventilation rates. Proc. of the Simp. Agribuilding, Campinas, Brasil: 136-151.

Boulard T and Baile A (1995) Modelling of air exchange rate in a greenhouse equipped with continuous roof vents. J. Agric. Eng. Res., 61: $37-48$.

Boulard T and Draoui B (1995) Natural ventilation of a greenhouse with continuous roof vents: measurement and data analysis. J. Agric. Eng. Res., 61: 27-36.

Boulard T, Roy JC, Pouillard JB, Fatnassi H, and Grisey A (2017) Modelling of micrometeorology, canopy transpiration and photosynthesis in a closed greenhouse using computational fluid dynamics. Biosys. Eng., 158: 110-133.

Bot GPA (1983) Greenhouse climate: from physical processes to a dynamic model. Thesis, Department of Physics and Meteorology, Agricultural University of Wageningen, the Netherlands.

Challa H and Schapendonk AHCM (1984) Dynamic optimization of $\mathrm{CO}_{2}$ concentration in relation to climate control in greenhouses. In: Carbon dioxide enrichment for greenhouse crops (Enoch, H.Z and Kimball, BA). pp. 147-160. CRC Press, Boca Raton.

Chalabi ZS and Fernandez JE (1994) Estimation of net photosynthesis of a greenhouse canopy using a mass balance method and mechanistic models. Agric. For. Meteorol., 71: 165-182.

Demrati H, Boulard T, Bekkaoui A, and Bouirden L (2001) Natural ventilation and microclimatic performance of a large-scale banana greenhouse. J. Agric. Eng. Res., 80: 261-271.

Dieleman JA, Bontsema J, Jalink H, Elings A, Kempkes FLK, Meinen E, and Snel JFH (2017) Development and validation of two crop photosynthesis monitoring systems to support greenhouse climate control. Acta. Hort., 1170: 1173-1179.

Ehler N (1991) An autocalibrating model for simulating and measuring net canopy photosynthesis using a standard greenhouse climate computer. Comput. Electron. Agric., 6: 1-20.

Fernandez JE and Bailey BJ (1992) Measurement and prediction of greenhouse ventilation rates. Agric. For. Meteorol.,58: $229-245$.

Fernandez JE and Bailey BJ (1993) Predicting greenhouse ventilation rates. Acta. Hort., 328:107-114.

Gijzen H and ten Cate JA (1988) Prediction of the response of greenhouse crop photosynthesis to environmental factors by integration of physical and biochemical models. Acta. Hort., 229: 251-258.

Gijzen H, Vegter JG, and Nederhoff, EM (1990) Simulation of greenhouse crop photosynthesis: validation with cucumber, sweet pepper, and tomato. Acta. Hort., 268: 71-80.

Goedhart M, Nederhoff EM, Udink ten Cate AJ, and Bot GPA (1984) Methods and instruments for ventilation rate measurements. Acta. Hort., 148: 393-400.

Hand DW (1973a) A Null balance method for measuring crop photosynthesis in an airtight daylit controlled-environment cabinet. Agric. Meteorol., 12: 259-270.

Hand DW (1973b) Techniques for measuring $\mathrm{CO}_{2}$ assimilation in controlled-environment enclosures. Acta. Hort., 32: $133-147$.

Hand DW (1985) The promise of enrichment. Grower Horticulture Now, 104: 31-37. 
Hand DW, Clark G, Hannah MA, Thornley JHM, and Wilson JW (1992) Measuring the canopy net photosynthesis of glasshouse crops. J. Exp. Bot., 43: 375-381.

Hao X, Wang Q, and Khosla S (2008) Responses of greenhouse tomatoes to summer $\mathrm{CO}_{2}$ enrichment. Acta. Hort., 797: $241-246$.

Harmanto, Tantau HJ and Salokhe VM (2006a) Influence of insect screens with different mesh sizes on ventilation rate and microclimate of greenhouses in the humid tropics. Agricultural Engineering International: the CIGR Ejournal. Manuscript BC 05 017, 8: 1-18.

Harmanto, Tantau HJ and Salokhe VM (2006b) Microclimate and air exchange rates in greenhouses covered with different nets in the humid tropics. Biosys. Eng., 94: 239-253.

Hunt S (2003) Measurements of photosynthesis and respiration in plants. Physiol. Plant., 117: 314-325.

Jolliet O and Bailey BJ (1992) The effect of climate on tomato transpiration in greenhouses: measurements and models comparison. Agric. For. Meteorol., 58: 43-62.

Katsoulas N, Baille A, and Kittas C (2001) Effect of misting on transpiration and conductances of a greenhouse rose canopy. Agric. For. Meteorol., 106: 233-247.

Katsoulas N, Bartzanas T, Boulard T, Mermier M, and Kittas C (2006) Effect of vent openings and insect screens on greenhouse ventilation. Biosys. Eng., 93: 427-436.

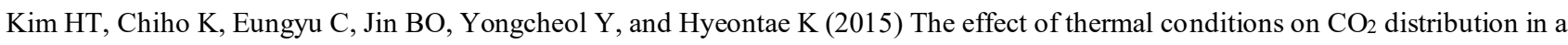
greenhouse. Trop. Agric. Res., 26: 714-720.

Kittas C, Boulard T, Mermier M, and Papadakis G (1996) Wind induced air exchange rates in a greenhouse tunnel with continuous side openings. J. Agric. Eng. Res., 65: 37-49.

Kittas C, Boulard T, Bartzanas T, Katsoulas N, and Mermier M (2002) Influence of an insect screen on greenhouse ventilation. Trans. ASAE, 45: 1083-1090.

Kuroyanagi T, Yasuba K, Higashide T, Iwasaki Y, and Takaichi M (2014) Efficiency of carbon dioxide enrichment in an unventilated greenhouse. Biosys. Eng., 119: 58-68.

Lake JV, Browne DA, and Bowman GE (1968) A glasshouse as a cuvette. In: Functioning of Terrestrial Eco-Systems at the Primary Production Level. Proc. Copenhagen Sym. UNESCO, pp. 329-333.

Lawlor DW, Day W, Johnston AE, Legg BJ, and Parkinson KJ (1981) Growth of spring barley under drought: crop development, photosynthesis, dry-matter accumulation, and nutrient content. J. Agric. Sci., 96: 167-186.

Lee J, Usami T, Oikawa T, and Lee H (2000) High performance of temperature gradient chamber newly built for studying global warming effect on a plant population. Korean J. Ecol., 23: 293-298.

Leperen W and Madery H (1994) A new method to measure plant water uptake and transpiration simultaneously. J. Exp. Bot., 45: 5160.

Li M, Kozai T, Niu G, and Takagaki M (2012) Estimating the air exchange rate using water vapor as a tracer gas in a semi-closed growth chamber. Biosys. Eng., 113: 94-101.

Li Y, Ding Y, Li D, and Miao Z (2018) Automatic carbon dioxide enrichment strategies in the greenhouse. Biosys. Eng., 171: $101-119$.

Marcelis LFM, Van den Boogard R, and Meinen E (2000) Control of crop growth and nutrient supply by the combined use of crop models and plant sensors. Proc. Int. Conf. Modelling and Control in Agriculture, Horticulture and Post-harvest Processing. IFAC, 351-356.

Mashonjowa E, Ronsse F, Milford J, Lemeur R, and Pieters JG (2010) Measurement and simulation of the ventilation rates in naturally ventilated azrom type greenhouse in Zimbabwe. J. Appl. Eng. Agric., 26: 475-488.

Millan-Almaraz JR, Guevara-Gonzalez RG, De Jesus Romero-Troncoso R, Osornio-Rios RA, and Torres-Pacheco I (2009) Advantages and disadvantages on photosynthesis measurement techniques. African. J. Biotechnol., 8: 7340-7349.

Muñoz P, Montero JI, Antón A, and Giuffrida F (1999) Effect of insect-proof screens and roof openings on greenhouse ventilation. J. Agric. Eng. Res., 73: 171-178.

Nederhoff EM, Gijzen H, Vegter JG, and Rijsdijk AA (1989) Dynamic model for greenhouse crop photosynthesis: validation by measurements and application for $\mathrm{CO}_{2}$ optimization. Acta. Hort., 260: 137-147.

Nederhoff EM and Vegter JG (1994) Photosynthesis of stands of tomato, cucumber, and sweet pepper measured in greenhouses under various $\mathrm{CO}_{2}$-concentrations. Ann. Bot., 73: 353-361.

Nederhoff EM, van de Vooren J, and ten Cate AJU (1985) A practical tracer gas method to determine ventilation in greenhouses. J. Agric. Eng. Res., 31: 309-319. 
Papadakis G, Mermier M, Meneses JF, and Boulard T (1996) Measurement and analysis of air exchange rates in a greenhouse with continuous roof and side openings. J. Agric. Eng. Res., 63: 219-227.

Rigakis N, Katsoulas N, Teitel M, Bartzanas T, and Kittas C (2015) A simple model for ventilation rate determination in screen houses. Energy Build., 87: 293-301.

Rodríguez F, Berenguel M, Guzman JL, and Ramırez-Arias A (2015) Modeling and control of greenhouse crop growth. Springer International Publishing. Switzerland.

Roy JC, Boulard T, Kittas C, and Wang S (2002) Convective and ventilation transfers in greenhouses, Part 1: the greenhouse considered as a perfectly stirred tank. Biosys. Eng., 83: 1-20.

Schulze ED (1972) A new type of acclimatized gas exchange chamber for net photosynthesis and transpiration measurements in the field. Oecologia, 10: 243-251.

Sherman MH (1990) Tracer-gas techniques for measuring ventilation in a single zone. Build. Environ., 25: 365-374.

Shimomoto K, Takayama K, Takahashi N, Nishina H, Inaba K, Isoyama Y, and Shin-Chu O (2020) Real-time monitoring of photosynthesis and transpiration of a fully-grown tomato plant in greenhouse. Environ. Control Biol., 58: 65-70.

Takahashi M, Ishiji T and Kawashima N (2001) Handmade oxygen and carbon dioxide sensors for monitoring the photosynthesis process as instruction material for science education. Sens. Actuators B. Chem., 77: 237-243.

Takakura T, Sunagawa H, Tamaki M, Usui T, and Taniai N (2017) In site net photosynthesis measurement of a plant canopy in a singlespan greenhouse. J. Adv. Agric., 7: 1015-1020.

Teitel M and Tanny J (1999) Natural ventilation of greenhouses: experiments and model. Agric. For. Meteorol., 96: 59-70.

Thongbai P, Kozai T, and Ohyama K (2010) $\mathrm{CO}_{2}$ and air circulation effects on photosynthesis and transpiration of tomato seedlings. Sci. Hort., 126: 338-344.

Thornley JHM, Hand DW, and Warren Wilson J (1992) Modelling canopy net photosynthesis of glasshouse row crops and application to cucumber. J. Exp. Bot., 43: 383-391.

Thwe AA, Vercambre G, Gautier H, Gay F, Phattaralerphong J, and Kasemsap P (2014) Response of photosynthesis and chlorophyll fluorescence to acute ozone stress in tomato (Solanum lycopersicum Mill.). Photosynthetica, 52: 105-116.

Wang S and Boulard T (2000) Predicting the microclimate in a naturally ventilated plastic house in a Mediterranean climate. J. Agric. Eng. Res., 75: 27-38.

Wang WZ, Zhang M, Liu CH, Li MZ, and Liu G (2013) Real-time monitoring of environmental information and modeling of the photosynthetic rate of tomato plants under greenhouse conditions. Appl. Eng. Agric., 29: 783-792.

Yasutake D, Tanioka H, Ino A, Takahashi A, Yokoyama T, Mori M, and Miyauchi K (2017) Dynamic evaluation of natural ventilation characteristics of a greenhouse with $\mathrm{CO}_{2}$ enrichment. Acad. J. Agric. Res., 5: 312-319.

Zabri AW and Burrage SW (1998) The effects of vapor pressure deficit (VPD) and enrichment with $\mathrm{CO}_{2}$ on photosynthesis, stomatal conductance, transpiration rate, and water use efficiency (WUE) of sweet pepper (Capsicum annuum L.) grown by NFT. Acta. Hort., 458: 351-356.

Zekki H, Gary C, Gosselin A, and Gauthier L (1999) Validation of a photosynthesis model through the use of the $\mathrm{CO}_{2}$ balance of a greenhouse tomato canopy. Ann. Bot., 84: 591-598.

Zhang J and Wang SX (2011) Simulation of the canopy photosynthesis model of greenhouse tomato. Procedia. Eng., 16: 632-639. 